\title{
Effective ascorbate-free and photolatent click reactions in water using a photoreducible copper(II)-ethylenediamine precatalyst
}

\author{
Redouane Beniazza ${ }^{1}$, Natalia Bayo ${ }^{1}$, Florian Molton², Carole Duboc², \\ Stéphane Massip ${ }^{3,4,5}$, Nathan McClenaghan ${ }^{1}$, Dominique Lastécouères ${ }^{1}$ \\ and Jean-Marc Vincent ${ }^{* 1}$
}

\section{Full Research Paper}

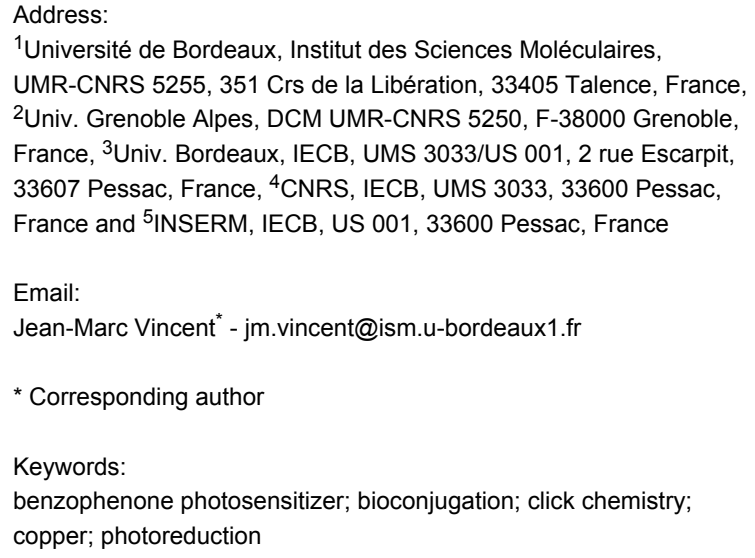

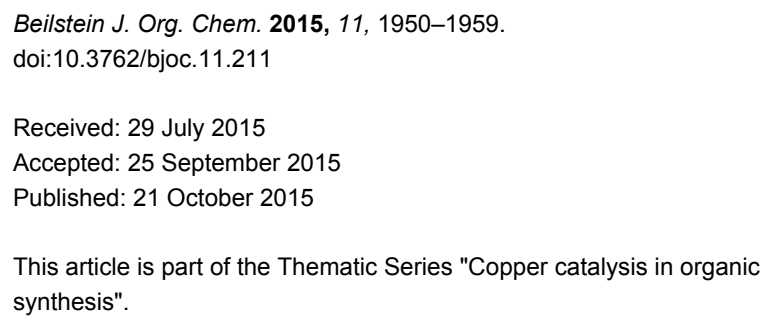

\begin{abstract}
The search for copper catalysts able to perform effectively click reactions in water in the absence of sodium ascorbate is an active area of current research with strong potential for applications in bioconjugation. The water-soluble and photoreducible copper(II)-EDA (EDA = ethylenediamine) complex 1, which has two 4-benzoylbenzoates acting as both counterion and photosensitizer, has been synthesized and characterized by different techniques including single crystal X-ray diffraction. Highly efficient photoreduction was demonstrated when solutions of $\mathbf{1}$ in hydrogen atom donating solvents, such as THF or $\mathrm{MeOH}$, were exposed to UVA radiation (350-400 nm) provided by a low pressure mercury lamp (type TLC = thin-layer chromatography, $365 \mathrm{~nm}$ ), or by a $23 \mathrm{~W}$ fluorescent bulb, or by ambient/sunlight. In water, a much poorer hydrogen atom donating solvent, the photoreduction of $\mathbf{1}$ proved inefficient. Interestingly, EPR studies revealed that complex 1 could nonetheless be effectively photoreduced in water when alkynes were present in solution. The catalytic activity of $\mathbf{1}$ for click reactions involving a range of water-soluble alkynes and azides, in particular saccharides, was tested under various illumination conditions. Complex $\mathbf{1}$ was found to exhibit a photolatent character, the photogenerated copper(I) being very reactive. On irradiating aqueous reaction mixtures containing $1 \mathrm{~mol} \%$ of $\mathbf{1}$ at $365 \mathrm{~nm}$ (TLC lamp) for $1 \mathrm{~h}$, click reactions were shown to proceed to full conversion.
\end{abstract}




\section{Introduction}

Since the discovery in 2002 that copper(I) could catalyze the Huisgen alkyne-azide [3 +2$]$ cycloaddition with high selectivity for the 1,4-triazole $[1,2]$, the so-called copper(I)-catalyzed alkyne-azide cycloaddition (CuAAC) has become a privileged reaction which is widely employed in all areas of the chemical/ biological/material sciences $[3,4]$. Numerous copper-based catalytic systems have been developed and employed for the $\mathrm{CuAAC}$ [5], the main prerequisite being the generation of a copper(I) catalytic species from various homogeneous/heterogeneous precatalysts, whose oxidation states are $0,+1$ or +2 . A major application of the CuAAC concerns bioconjugation reactions, i.e., the covalent modification of biomolecules [6]. Such reactions typically imply water-soluble alkyne and azide reactants and should thus be performed in an aqueous medium using a water-soluble catalyst. Important limitations for such transformations are: (i) high copper loading, often used in excess with respect to the substrates, due to limited catalyst reactivity and the fact that the substrates (proteins, oligonucleotides or oligosaccharides) are typically used in dilute conditions; (ii) contamination of the products by copper salts, which should be avoided for in vivo applications and, when employed, by sodium ascorbate and/or its byproducts; (iii) side-reactions on the substrates due to the generation of reduced dioxygenactive species and/or reactive oxidized byproducts of ascorbate. In a seminal paper, Finn and coworkers addressed several of these points; they proposed an optimized catalytic system composed of $\mathrm{CuSO}_{4}$, an accelerating and water-soluble tris-triazole THPTA (tris[(1-hydroxypropyl-1H-1,2,3-triazol-4yl)methyl]amine) ligand with a ligand/copper ratio equal to at least 5 to effectively trap the reactive oxygenated species [7]. They also show that aminoguanidine could be added to the reaction mixture to effectively trap the reactive byproducts derived from ascorbate oxidation. Using these protective additives (excess of ligand and guanidine) bioconjugation reactions could be conducted from a $\mathrm{Cu}$ (II) precatalyst even when the reaction mixture is exposed to air. Optimized ligands leading to faster kinetics were later developed [8,9], allowing for instance to lower the copper loading, which is important to avoid toxicity issues for applications with living cells [9]. An interesting catalyst was reported by Gautier and coworkers based on a water-soluble $\mathrm{Cu}(\mathrm{I})-\mathrm{NHC}$ complex, which could be used under ascorbate-free and open air conditions for the CuAAC ligation of oxidation-sensitive peptides in buffered aqueous media [10].

Recently, we developed the photoreducible copper(II) complexes 2 and 3 incorporating a tren (tren $=\operatorname{tris}(2-$ aminoethyl)amine) ligand derivative $[11,12]$ or the dmeda (dmeda $=N, N^{\prime}$-dimethylethylenediamine) ligand $[13,14]$ (Scheme 1). Irradiation at $365 \mathrm{~nm}$ of the benzophenone photosensitizer ( $n \rightarrow \pi^{*}$ electronic transition), introduced through the carboxylate counterion, mediated a highly efficient photoinduced electron transfer process leading to a fast $\mathrm{Cu}$ (II) to $\mathrm{Cu}$ (I) reduction, the final electron source being the solvent. The photoreduction process was extremely efficient, photoreduction quantum yields $\left(\Phi_{\text {red }}\right)$ ranging from 0.17 up to around 1 being measured in good H-atom donating solvents such as $\mathrm{MeOH}$ or THF [11-13]. Consequently, efficient reduction could be achieved by simply exposing the solutions of the $\mathrm{Cu}$ (II) complexes to ambient light. Importantly, the photogenerated $\mathrm{Cu}(\mathrm{I})$ species were shown to be extremely reactive for the $\mathrm{CuAAC}$ reaction when conducting the reactions in organic

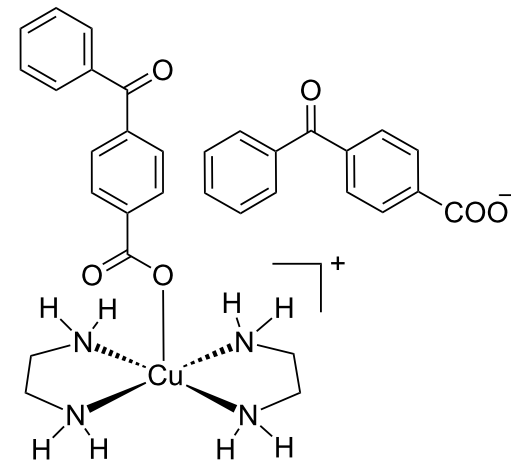

1

This study

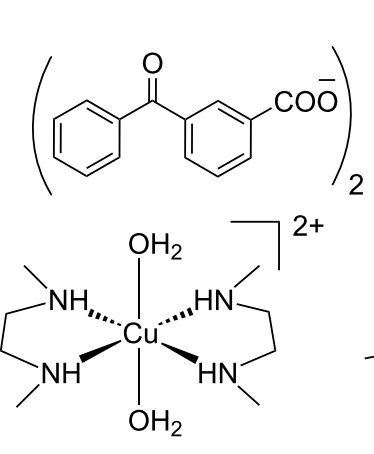

2

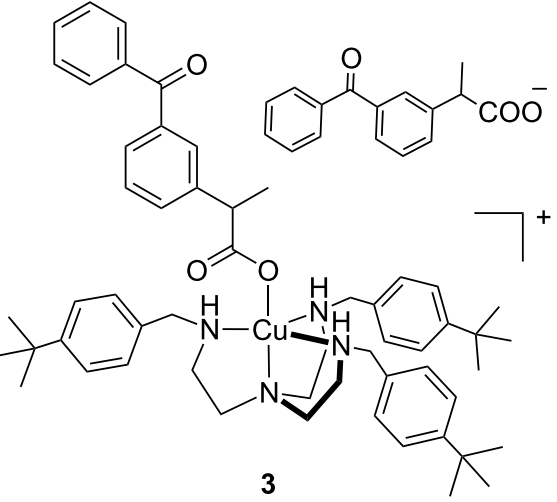

Previous studies 
solvents, typically $\mathrm{MeOH}$, THF or toluene. It should be noted that within the last four years, other photoreducible copper(II)based catalytic systems applied to click chemistry have been reported [15-27], in particular for the preparation of polymers [15-24].

We wish now to report on our preliminary studies dealing with the water-soluble complex $\mathbf{1}$, the objective being to develop photoactivable click copper(II) precatalysts which could be used in aqueous solution and ascorbate-free conditions. We describe here the synthesis and characterization of $\mathbf{1}$, its photoreduction properties in various solvents and illumination conditions, and its catalytic properties which reveal that $\mathbf{1}$, when illuminated, is an effective photolatent click catalyst in aqueous medium.

\section{Results and Discussion}

The EDA (EDA = ethylenediamine) ligand in the copper(II) complex $\left[\mathrm{Cu}^{\mathrm{II}}(\mathrm{EDA})_{2}\right.$ (4-benzoylbenzoate)](4-benzoylbenzoate) (1) was chosen to ensure high water solubility. Complex 1 was synthesized in two steps by first preparing the copper(II)carboxylate dimer $\left.\left[\mathrm{Cu}_{2} \text { (4-benzoylbenzoate }\right)_{4}(\mathrm{THF})_{2}\right] \mathbf{4}$ which was obtained by reacting 2 equivalents of the sodium salt of the 4-benzoylbenzoic acid with $\mathrm{Cu}(\mathrm{OTf})_{2}$ in water, the precipitate which formed being recrystallized by slow diffusion of $\mathrm{Et}_{2} \mathrm{O}$ in a THF solution (Scheme 2). Then, 4 equivalents of EDA were reacted with 4 in THF, the solution immediately turned deep blue. Slow diffusion of diethyl ether vapour into the THF solution led to the crystallization of $\mathbf{1}$ as blue needles, which were recovered by filtration ( $71 \%$ yield).

The proposed dinuclear and mononuclear structures of $\mathbf{4}$ and $\mathbf{1}$ were confirmed by single crystal X-ray diffraction (Figure 1). The crystal structure of $\mathbf{4}$ displays the typical "paddle-wheel" of copper(II)-carboxylate complexes [28], a structure in which the two copper(II) ions are bridged by four carboxylates in a syn-syn configuration $\left(d_{\mathrm{Cu}}{ }^{\cdots} \mathrm{Cu} 2.613 \AA\right)$, whilst two THF molecules occupy axial coordination sites.

Complex 1 displays a monomeric structure with a distorted square pyramidal geometry with the copper ion lying slightly above the basal plane formed by 4 nitrogen atoms (average $\left.d_{\mathrm{Cu} \cdots \mathrm{N}} 2.019 \AA\right)$, while an oxygen atom of a carboxylate occupies the axial site $\left(d_{\mathrm{Cu} \cdots \mathrm{O}} 2.294 \AA\right)$. The oxygen atom of the $\mathrm{C}=\mathrm{O}$ bond is participating in one intramolecular $\left(d_{\mathrm{CO}} \cdots \mathrm{HN}\right.$ $2.140 \AA)$ and one intermolecular $\left(d_{\mathrm{CO} \cdots \mathrm{HN}} 2.212 \AA\right)$ hydrogen bond with hydrogen atoms of EDA ligands. The second carboxylate anion is not directly bound to the copper(II) ion, but participates in four intermolecular hydrogen bonds with hydrogen atoms of EDA (average $d_{\mathrm{CO}} \cdots \mathrm{HN} 2.125 \AA$ ) ligands of two $\left[\mathrm{Cu}(\mathrm{EDA})_{2} \text { (4-benzoylbenzoate) }\right]^{+}$cations.

Aqueous and THF solutions of $\mathbf{1}$ were characterized by a shift of the absorption band ( $\mathrm{d}-\mathrm{d}$ electronic transition) in the visible spectral region from $550 \mathrm{~nm}$ in water to $606 \mathrm{~nm}$ in THF (spectra at $t=0 \mathrm{~min}$ in Figure 2). This was ascribed to the ion-pair dissociation state of the complex with water molecules being most probably bound to the copper ions in aqueous solution, while in THF, the carboxylates interact more tightly with the copper ions. This is in agreement with the ${ }^{1} \mathrm{H}$ NMR spectra of 1, which showed well resolved peaks for the benzophenone protons in $\mathrm{D}_{2} \mathrm{O}$, while in THF- $d_{8}$ broad resonances were observed, as expected for a compound interacting more strongly with paramagnetic copper(II) ions. It should be noted that the methylene protons of the EDA ligands are not observed.

Photoreduction studies of $\mathbf{1}$ were then conducted varying both the solvent and illumination conditions. The first experiments were carried out in quartz cuvettes to follow the disappearance of the low-energy visible light absorption band (550-600 nm)

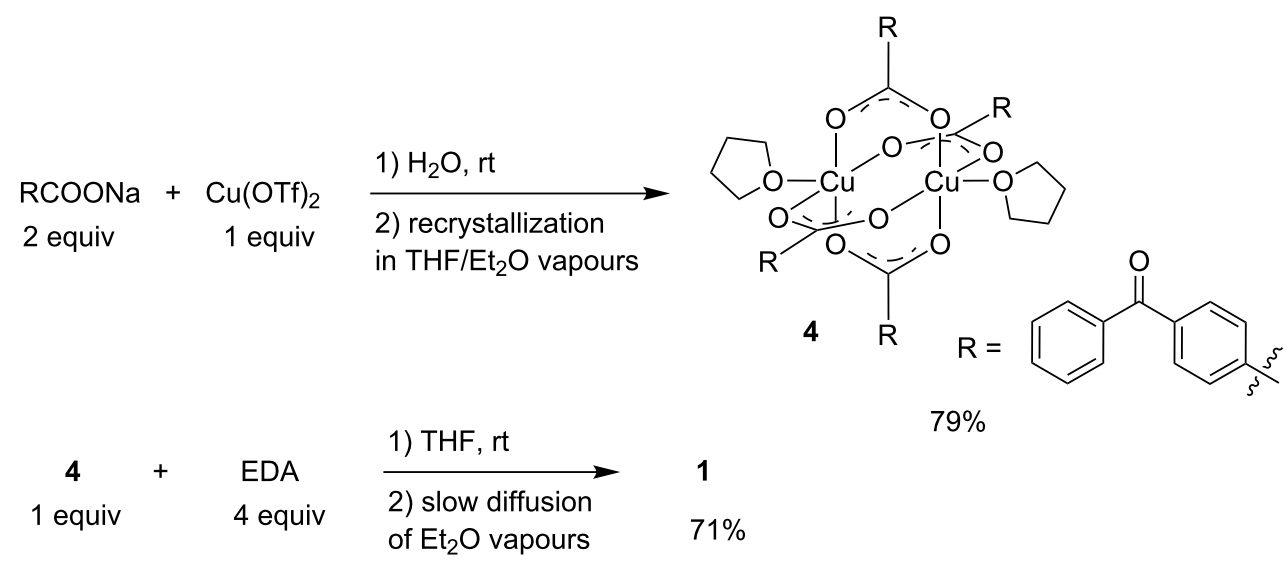

Scheme 2: Syntheses of complexes 1 and 4. 

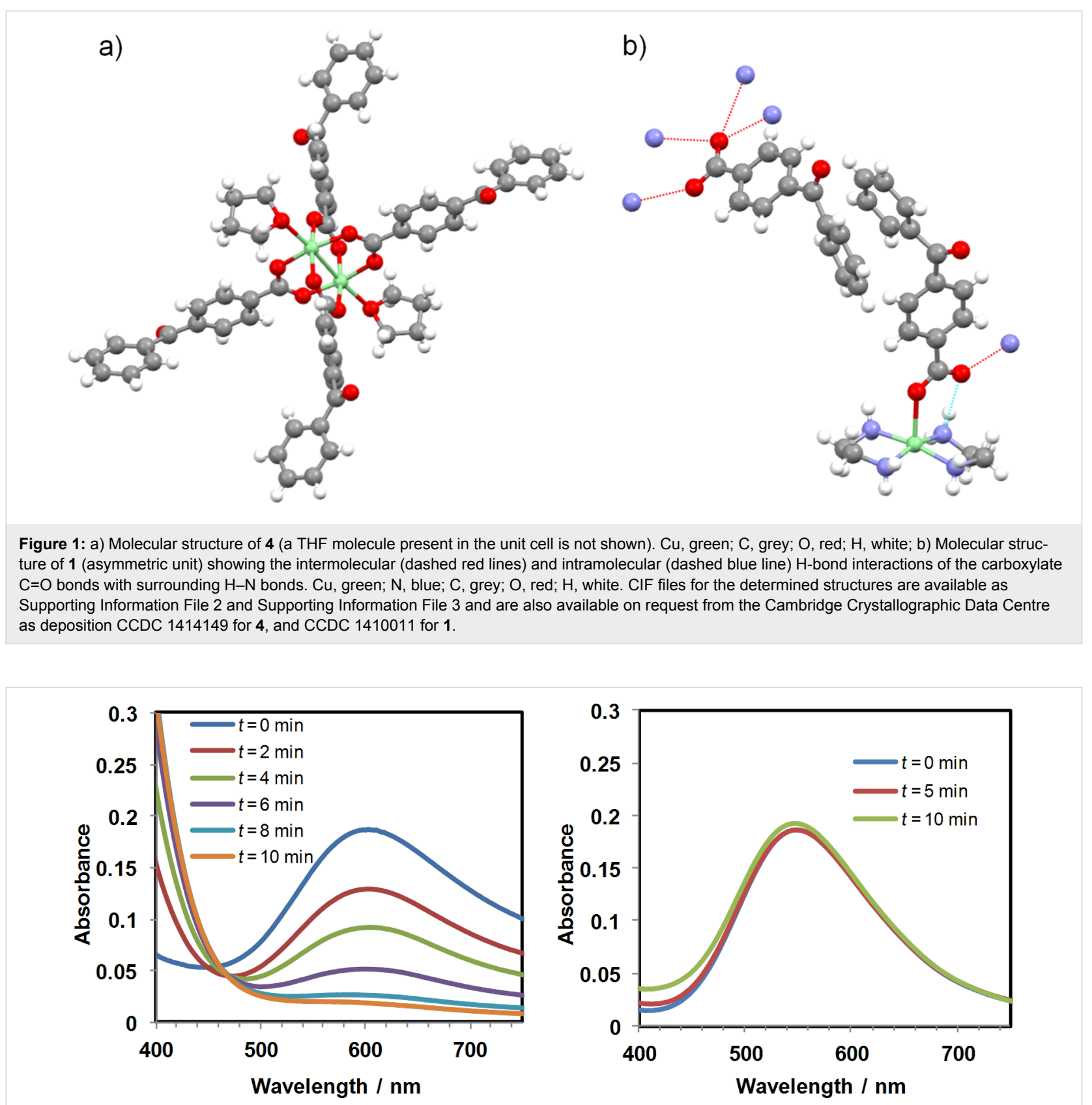

Figure 2: Evolution of the UV-vis spectra of deaerated (freeze-pump-thaw degassed, sealed quartz cuvettes) THF (left) or water (right) solutions $(3 \mathrm{~mL})$ of complex $1(2 \mathrm{mM})$ under irradiation at $365 \mathrm{~nm}$ using a TLC lamp placed at $\approx 1 \mathrm{~cm}$ from the cuvette.

ascribed to a d-d electronic transition, which is typical for $\mathrm{Cu}^{\mathrm{II}}$ complexes $\left(d^{9}\right)$. The reductions were typically conducted under strictly anaerobic conditions, deaeration of the solutions being achieved either by gentle Ar bubbling through a rubber cap or, by freeze-pump-thaw cycles followed by sealing of the cell. Irradiations were performed at wavelengths compatible with the $\mathrm{n} \rightarrow \pi^{*}$ electronic transition of the benzophenone chromophore, i.e., $\approx 350-370 \mathrm{~nm}$ (UVA). Illumination of the samples at $365 \mathrm{~nm}$ using a TLC lamp thus represents a convenient source of light. Previous studies revealed that a $2 \mathrm{mM}$ solution of $\mathbf{2}$ in
THF ( $3 \mathrm{~mL}$ in a quartz cuvette with $1 \mathrm{~cm}$ path length) was fully reduced in $\approx 15 \mathrm{~min}$ [14]. Interestingly, the photoreduction process was found to be so effective, that the UVA photons (350-400 nm) present in sunlight/ambient light were sufficient to achieve the reduction with satisfactory rates, i.e., $\approx 30 \mathrm{~min}$ and $60 \mathrm{~min}$ when the samples were exposed behind a window to direct light of a sunny or a rainy day, respectively. It should also be noted that over-reduction processes leading to the formation of copper(0) nanoparticles occurred when prolonged irradiation times were applied $[12,13]$. 
When a deaerated solution of $\mathbf{1}$ in THF was irradiated at $365 \mathrm{~nm}$, a very fast change of the solution aspect was observed, the solution becoming colourless in $\approx 10 \mathrm{~min}$ as shown by UV-vis spectroscopy (Figure 2). This rate is comparable to that observed previously with the analogous complex 2 , for which a photoreduction quantum yield close to unity has been determined in THF [14]. Because of such a high efficiency, the photoreduction proceeded well under direct sunlight illumination by placing the quartz cuvette behind a window of a sunny day, $\approx 60 \%$ of 1 being reduced in 40 min illumination under such conditions.

When irradiations were conducted on aqueous solutions of $\mathbf{1}$, no reduction was observed, as revealed in Figure 2. This agrees with the poor hydrogen atom donating character of $\mathrm{H}_{2} \mathrm{O}$ $(\mathrm{BDE}=119 \mathrm{kcal} / \mathrm{mol})$ compared to THF $(\mathrm{BDE}=92 \mathrm{kcal} / \mathrm{mol})$, the reactivity of the excited triplet of benzophenone being particularly high toward the THF moiety [29].

At this stage, a reduction mechanism implying the fast generation of the ketyl radical in good hydrogen atom donating solvents, which then can reduce the copper(II) ion to generate the copper(I) and regenerate the benzophenone chromophore, could be proposed (Scheme 3). Further studies, which aim to validate this proposal, are in progress.
The poor reduction efficiency observed in water could represent a serious limitation for our goal to develop photolatent click catalysts for reactions conducted in water with watersoluble reactants. However, under catalytic conditions, i.e., in the presence of a large excess of alkyne and azide ( $1 \mathrm{~mol} \%$ of $\mathbf{1}$ will be used for catalytic reactions), the reactants could be used as reducing agent. For instance, it has been previously shown that the alkynes could favor the $\mathrm{Cu}$ (II) to $\mathrm{Cu}(\mathrm{I})$ reduction, most probably through the well-known Glaser-type oxidative coupling [30,31]. We thus tested the reduction in the presence of the water-soluble alkynes 5-7. In marked contrast with experiments conducted in pure water, the aqueous solution irradiated in the presence of alkyne 5 (50 equiv with respect to copper), rapidly evolved to become slightly cloudy. Such changes, which could be ascribed to the formation of insoluble polymeric copper(I) acetylides and/or the insoluble 3-benzoylbenzoic acid (Scheme 3), precluded the use of UV-vis spectroscopy to quantitatively analyze the reductive process. For such an analysis, EPR spectroscopy was thus employed to assess the extent of copper reduction.

In Figure 3, the EPR spectra of solutions of $1\left(\mathrm{~d}^{9}, S=1 / 2\right)$ recorded by irradiating the samples directly in the probe at room temperature are presented. Control experiments conducted in THF and aqueous solutions of $\mathbf{1}$ (Figure $3 \mathrm{a}$ and b, respectively),

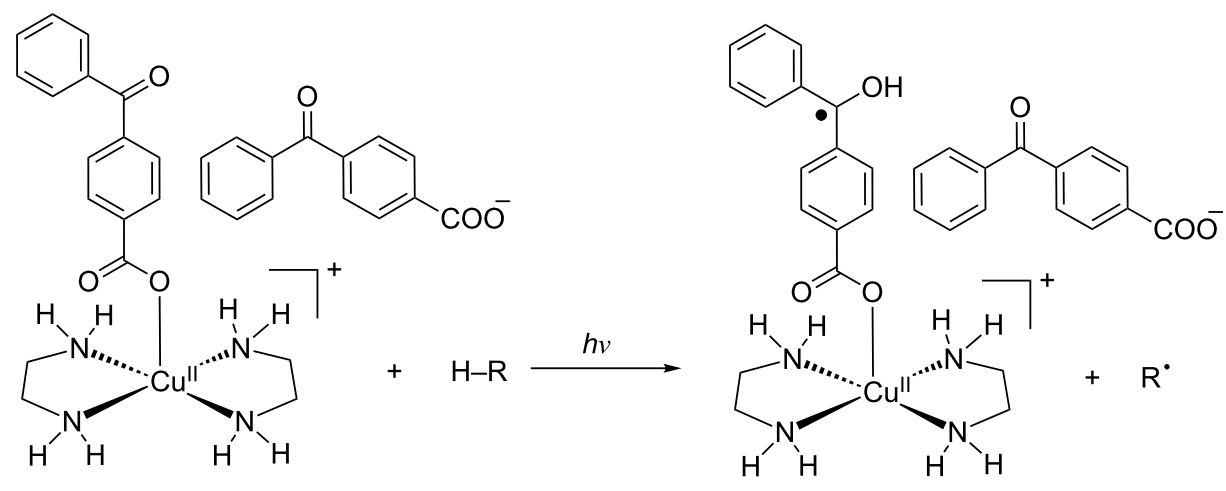

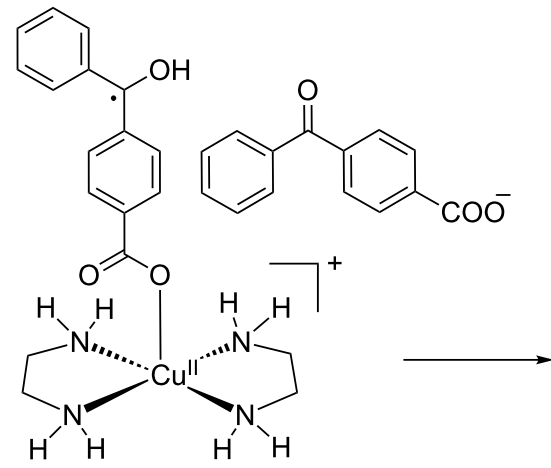<smiles>NCCNC(NCCN)OC(=O)c1ccc(C(=O)c2ccccc2)cc1</smiles><smiles>O=C(O)c1ccc(C(=O)c2ccccc2)cc1</smiles> 

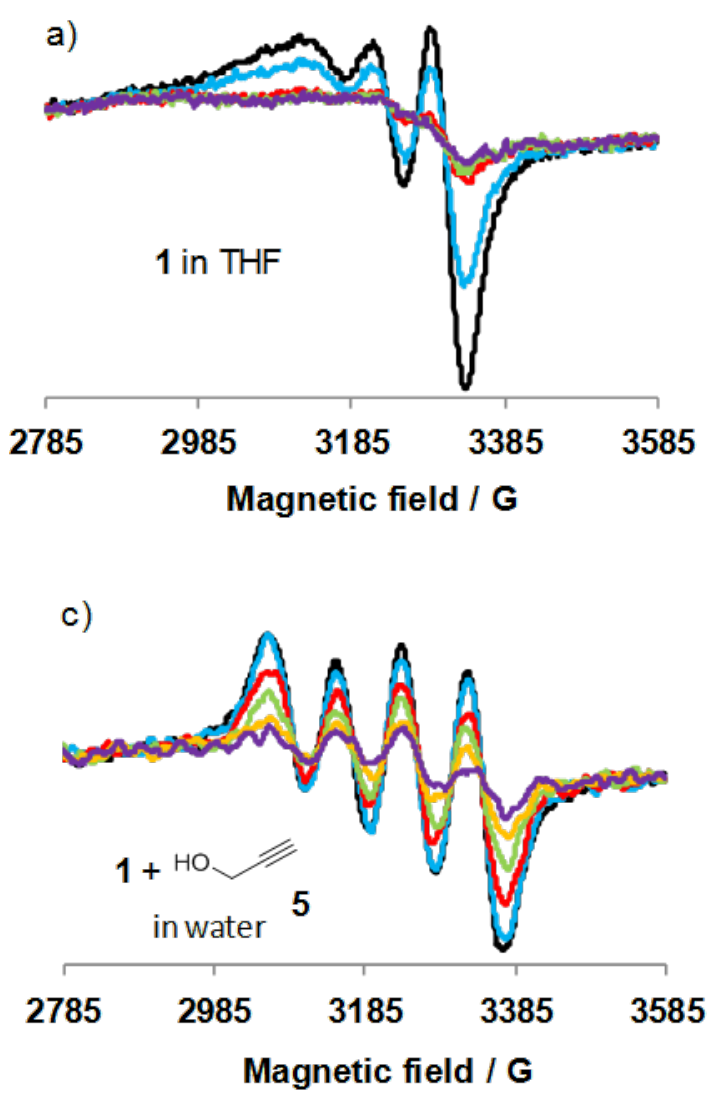
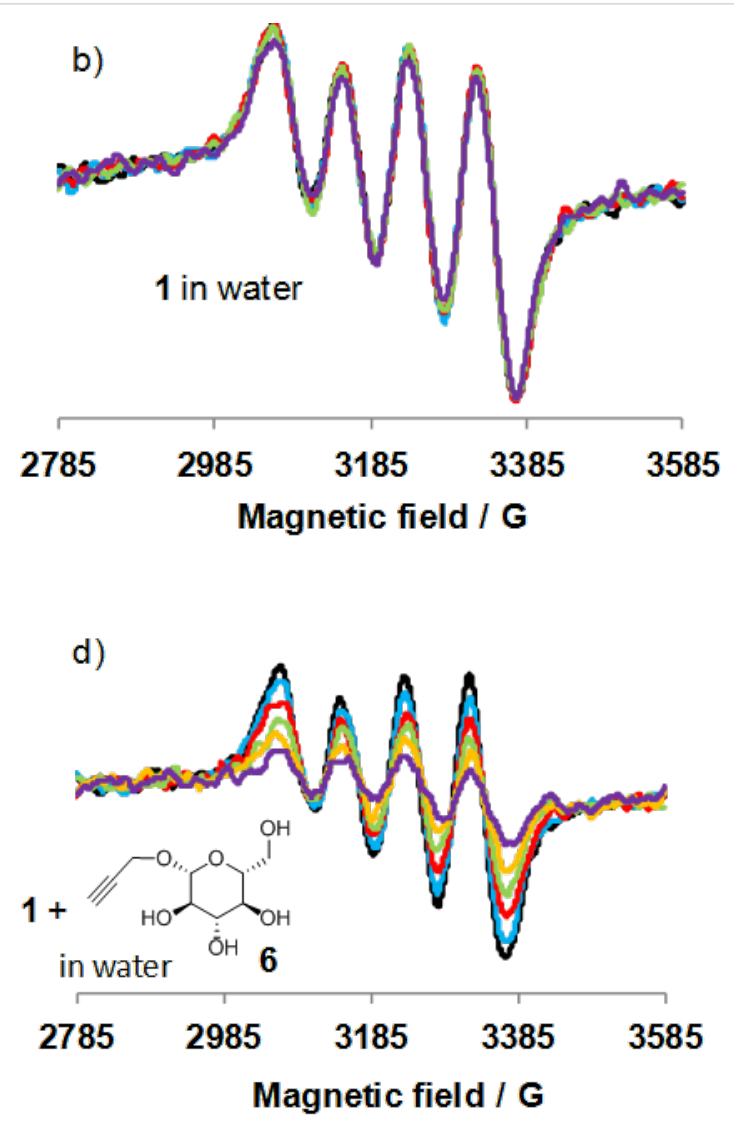

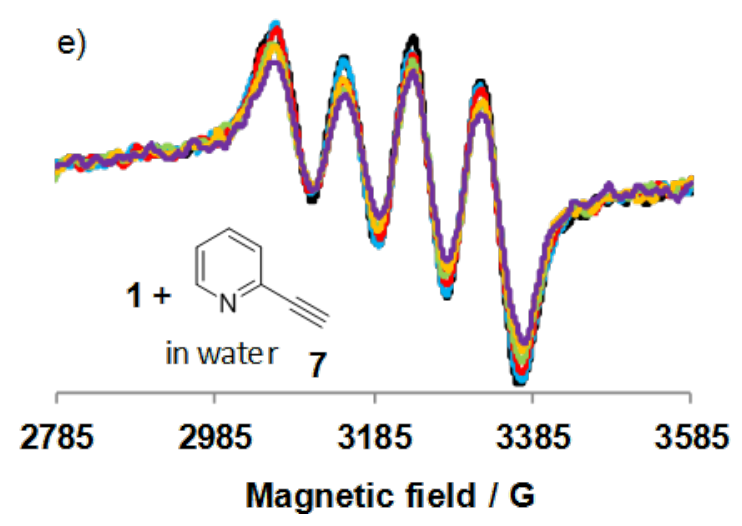

Figure 3: Evolution of the EPR spectra ( $X$ band, $298 \mathrm{~K}$ ) of solutions of 1 under continuous irradiation ( $280-400 \mathrm{~nm})$. A spectrum is recorded in the dark (black), then the light is switched on and the spectra (scanning time $=15 \mathrm{~s}$ ) recorded during irradiation at times $0 \mathrm{~s}$ (blue), $50 \mathrm{~s}$ (red), $100 \mathrm{~s}$ (green), $150 \mathrm{~s}$ (orange) and $225 \mathrm{~s}$ (purple). a) THF solution of 1 (1 mM); b) $\mathrm{H}_{2} \mathrm{O}$ solution of 1 (1 mM); c) $\mathrm{H}_{2} \mathrm{O}$ solution of 1 (1 mM) and alkyne 5 $(50 \mathrm{mM}) ;$ d) $\mathrm{H}_{2} \mathrm{O}$ solution of $1(1 \mathrm{mM})$ and alkyne $\left.6(50 \mathrm{mM}) ; \mathrm{e}\right) \mathrm{H}_{2} \mathrm{O}$ solution of $1(1 \mathrm{mM})$ and alkyne $7(50 \mathrm{mM})$.

confirmed the results gathered by UV-vis spectroscopy, i.e., fast reduction in THF and essentially no reduction in water. In water solution, the EPR spectra displays the four well-resolved hyperfine lines, expected for $\mathrm{Cu}(\mathrm{II})$ characterized by a nuclear spin of 3/2. However, the shape of the EPR spectra are different in both solvents in agreement with the UV-vis data, i.e., a water molecule should replace the $\mathrm{Cu}$-bound benzoylbenzoate in aqueous solution.
When the water-soluble alkynes $\mathbf{5 , 6}$ or $\mathbf{7}$ were added (50 equiv with respect to $\mathrm{Cu}$ ) and the aqueous solution irradiated, a decrease of the intensity of the EPR signal was observed, in agreement with a reduction process (Figure $3 \mathrm{c}-\mathrm{e}$ ). In the presence of propargyl alcohol 5 or propargyl ether $\mathbf{6}$ the reductions occurred very efficiently, i.e., $\approx 65 \%$ of the copper(II) (estimated by integration of the EPR signal) was reduced after $250 \mathrm{~s}$ of irradiation. This is nonetheless slower than in THF, in which 


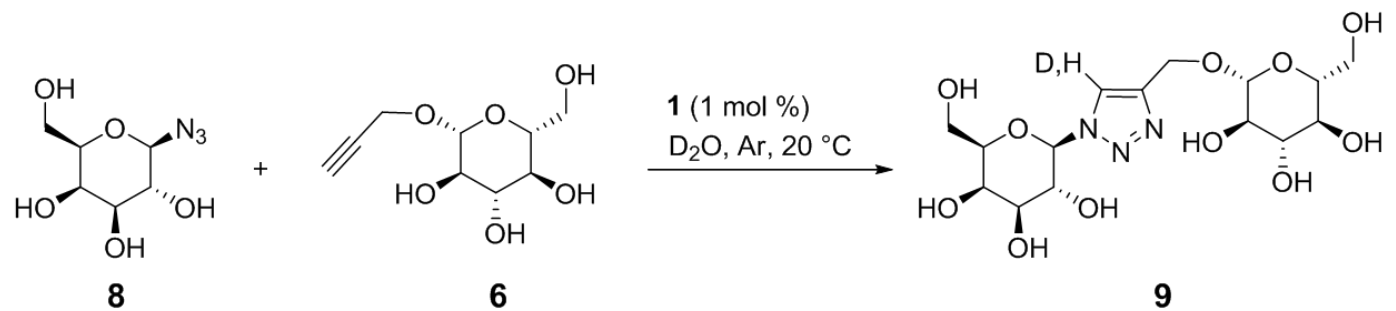

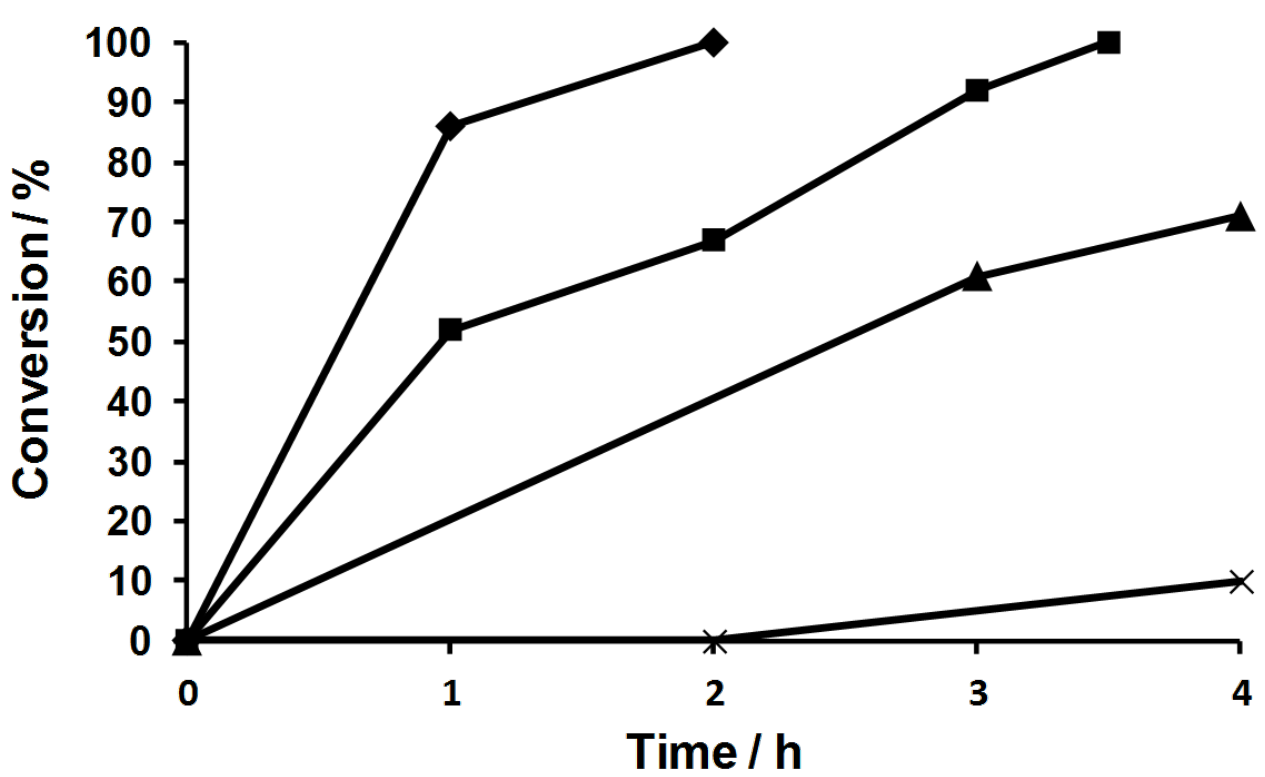

Figure 4: Reaction profiles for the formation of 9 under various illumination conditions: TLC lamp (365 nm) for $1 \mathrm{~h}$, then ambient laboratory light ( $\bullet$ ); tube in the dark $(\mathrm{X})$; tube exposed to ambient laboratory light $(\mathbf{\Lambda})$; tube exposed to $23 \mathrm{~W}$ fluorescent bulb $(\mathbf{\square})$.

$\approx 65 \%$ of 1 was reduced after only 40 s. With 2-alkynylpyridine 7 , reduction was also observed albeit at a slower rate, $\approx 35 \%$ of 1 being reduced after $250 \mathrm{~s}$ of irradiation. It is important to note that no reduction was observed in the absence of light, showing that the reduction is a photoinduced process. It also shows that if light-independent reduction is occurring, most probably through a Glaser-type oxidative coupling, it is a much slower process. At this stage, we propose that the alkynes serve as the hydrogen atom source to generate the ketyl radical of the benzophenone (Figure 2).

The photolatent properties of $\mathbf{1}$ and the reactivity of the photogenerated copper(I) species were then tested under various illumination conditions (Figure 4). Reactions between the watersoluble alkyne 6 and azide 8 were conducted in $\mathrm{D}_{2} \mathrm{O}$ in NMR tubes, thereby allowing convenient monitoring of the reaction progress. In a typical experiment, the NMR tube was charged with $1(1 \mathrm{~mol} \%), \mathrm{D}_{2} \mathrm{O}(0.5 \mathrm{~mL})$, the reactants $(0.15 \mathrm{mmol}$ each) and capped with a rubber septum. The whole tube was protected from light by aluminum foil, the solution was degassed by gentle Ar bubbling (20 min), and the tube was tightly capped with parafilm to limit air entry. The reactions were initiated by exposing the tubes to various light sources. In a first experiment the solution was irradiated for $1 \mathrm{~h}$ at $365 \mathrm{~nm}$ with a TLC lamp placed at $\approx 1 \mathrm{~cm}$ from the tube, and then left under ambient laboratory light. In these conditions, the reaction proceeded to full conversion in $\approx 2 \mathrm{~h}, 80-90 \%$ of the triazole being formed after $1 \mathrm{~h}$. The triazole 9 was then isolated in $91 \%$ yield. Importantly and in marked contrast, when the tube was protected from light, no reaction occurred within $2 \mathrm{~h}$, highlighting the photolatent behavior of $\mathbf{1}$. However a slow reaction was observed, $\approx 10 \%$ conversion was obtained in $4 \mathrm{~h}$, and $74 \%$ in $8 \mathrm{~h}$. This could be ascribed to the light-independent slow generation of copper(I) through Glaser-type oxidative coupling.

The catalytic system was found to be very sensitive to light. By simply leaving the tube exposed to ambient laboratory light after degassing, 70\% conversion was reached in $4 \mathrm{~h}$, the full conversion being attained in $7 \mathrm{~h}$. Interestingly, from a practical viewpoint, it is possible to simply illuminate the sample with a 
household fluorescent bulb $(23 \mathrm{~W})$ which produces a significant amount of UVA photons. Using this light source, full conversion was achieved in $3.5 \mathrm{~h}$, which is faster than when exposed to ambient light, but significantly slower than when exposed to TLC lamp.

Having established the most efficient illumination conditions, reactions were conducted on a range of water-soluble alkynes and azides by irradiating the NMR tubes with the TLC lamp for $1 \mathrm{~h}$ and then leaving it under ambient light. As seen in Scheme 4, a variety of triazoles $\mathbf{9 - 1 7}$ could be obtained in good isolated yields with reaction times ranging from $30 \mathrm{~min}$ to $8 \mathrm{~h}$. Again, no or little reaction was observed when protecting the tube from light, in agreement with photolatent catalysis.
Finally, two reactions were conducted in $\mathrm{H}_{2} \mathrm{O}$ on preparative scales in round-bottom flasks (Scheme 5). The hydrogenated triazoles 18 and 19 were obtained in $86 \%(0.450 \mathrm{~g})$ and $82 \%$ $(0.644 \mathrm{~g})$ isolated yields, respectively, showing that the procedure is practical for laboratory-scale applications.

\section{Conclusion}

The copper(II) precatalyst 1 incorporating a benzophenone chromophore is easily prepared, soluble in polar solvents and water, and can be stored indefinitely under ambient conditions. It is efficiently photoreduced in THF using convenient light sources producing UVA photons. While the $\mathrm{Cu}$ (II) to $\mathrm{Cu}(\mathrm{I})$ reduction process in water proved inefficient we have shown, in particular using EPR spectroscopy, that the alkynes can serve as

$$
\mathrm{R}^{-\mathrm{N}_{3}}+\mathrm{H}_{h v(365 \mathrm{~nm}) 30-60 \mathrm{~min}}^{\mathrm{R}^{1}} \underset{\mathrm{D}_{2} \mathrm{O}, \mathrm{Ar}, 20^{\circ} \mathrm{C}}{\mathrm{C}(1 \mathrm{~mol} \%)}
$$<smiles>[2H]c1c(CO[C@@H]2O[C@H](CO)[C@@H](O)[C@H](O)[C@H]2O)nnn1C1OC(CO)[C@@H](O)[C@H](O)[C@H]1O</smiles>

9

light: $120 \min , 100 \%(91 \%)$

dark: $120 \mathrm{~min}, 0 \%$<smiles>NC(=O)N[C@H]1[C@H](O)[C@@H](O)[C@@H](CO)O[C@H]1n1nnc(CO)c1P</smiles>

12

light: $480 \mathrm{~min}, 100 \%(81 \%)$ dark: $360 \mathrm{~min}, 0 \%$<smiles>[2H]c1c(CO)nnn1C1OC(CO)[C@@H](O)[C@H](O)[C@H]1O</smiles>

10

light: $30 \mathrm{~min}, 100 \%$ (94\%) dark: $30 \mathrm{~min}, 0 \%$<smiles>OCCc1nnn(C2OC(CO)[C@@H](O)[C@H](O)[C@H]2O)c1P</smiles>

11

light: $120 \mathrm{~min}, 100 \%$ (94\%) dark: $120 \mathrm{~min}, 0 \%$<smiles>[2H]c1c(-c2ccccn2)nnn1[C@@H]1O[C@H](CO)[C@@H](O)[C@H](O)[C@H]1O</smiles>

14

light: $450 \mathrm{~min}, 100 \%$ (93\%) dark: $360 \mathrm{~min}, 0 \%$ light: 240 min, $100 \%$ (89\%)

dark: $240 \mathrm{~min}, 9 \%$<smiles>[2H]c1c(CO[C@@H]2O[C@H](CO)[C@@H](O)[C@H](O)[C@H]2O)nnn1CCCO</smiles>

15

light: 90 min, 100\% (70\%)

dark: $120 \mathrm{~min}, 0 \%$<smiles>[2H]c1c(CO[C@@H]2O[C@H](CO)[C@@H](O)[C@H](O)[C@H]2O)nnn1[C@@H]1[C@@H](O)O[C@H](CO)[C@@H](O)[C@H]1O</smiles>

16

light: $240 \mathrm{~min}, 100 \%$ (87\%)

dark: $240 \mathrm{~min}, 0 \%$<smiles>OCCCn1nnc(CO)c1P</smiles>

light: $30 \mathrm{~min}, 100 \%$ (90\%)

dark: $30 \mathrm{~min}, 0 \%$ 
<smiles>NC1OC(CO)[C@H](O)[C@H](O)[C@H]1O</smiles>

$8 \quad 2 \mathrm{mmol}$

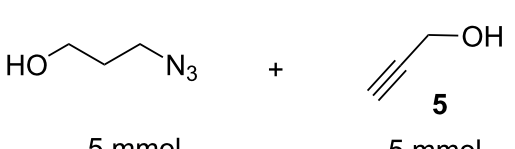

$5 \mathrm{mmol}$

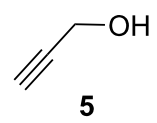

$2 \mathrm{mmol}$

$1(1 \mathrm{~mol} \%)$

$\underset{\operatorname{hv}(365 \mathrm{~nm}) 60 \mathrm{~min}}{\stackrel{\mathrm{H}_{2} \mathrm{O}, \mathrm{Ar}, 20{ }^{\circ} \mathrm{C}}{\longrightarrow}}$

$86 \%$

$1(1 \mathrm{~mol} \%)$
$\stackrel{\mathrm{H}_{2} \mathrm{O}, \mathrm{Ar}, 20{ }^{\circ} \mathrm{C}}{\longrightarrow}$

$82 \%$<smiles>OCc1cn([C@@H]2O[C@H](CO)[C@@H](O)[C@H](O)[C@H]2O)nn1</smiles>

18<smiles>OCCCn1cc(CO)nn1</smiles>

19

Scheme 5: Preparative scale synthesis of 18 and 19.

effective and practical electron source to allow the reduction in a light-dependent process photosensitized by the benzophenone. Complex 1 proved to be an effective photolatent catalyst for reactions conducted in water involving water-soluble alkynes and azides. Combining 1 with light, thus prevents the use of sodium ascorbate as reducing agent while a copper(II) complex is employed as precatalyst. The reactions were conducted not only under ascorbate-free conditions, but also under dioxygenfree conditions, deoxygenation being conveniently performed by $\mathrm{Ar}$ or $\mathrm{N}_{2}$ bubbling. Copper(I)-catalyzed processes, in particular for application in click bioconjugations, should be conducted under deaerated conditions in order to reduce copper loading due to fast $\mathrm{Cu}(\mathrm{I})$ to $\mathrm{Cu}(\mathrm{II})$ oxidation process mediated by $\mathrm{O}_{2}$, and also to limit addition of trapping agents to capture reactive oxygen species generated through side reactions between $\mathrm{Cu}(\mathrm{I})$ and $\mathrm{O}_{2}$.

\section{Supporting Information}

\section{Supporting Information File 1}

Experimental and analytical data.

[http://www.beilstein-journals.org/bjoc/content/ supplementary/1860-5397-11-211-S1.pdf]

\section{Supporting Information File 2}

Crystallographic Information for compound $\mathbf{1}$.

[http://www.beilstein-journals.org/bjoc/content/ supplementary/1860-5397-11-211-S2.cif]

\section{Supporting Information File 3}

Crystallographic Information for compound 4. [http://www.beilstein-journals.org/bjoc/content/ supplementary/1860-5397-11-211-S3.cif]

\section{Acknowledgments}

The authors are thankful to Dr. Thierry Buffeteau for the recording of the IR spectra of complexes 1 and 4 . The University of Bordeaux, the CNRS, the Région Aquitaine, the ANR (ANR-13-BS07-0006-01), the European Research Council (FP7/2008-2013) ERC grant agreement no. 208702 and IR-RPE CNRS 3443 are gratefully acknowledged for their financial support.

\section{References}

1. Rostovtsev, V. V.; Green, L. G.; Fokin, V. V.; Sharpless, K. B. Angew. Chem., Int. Ed. 2002, 41, 2596-2599. doi:10.1002/1521-3773(20020715)41:14<2596::AID-ANIE2596>3.0.CO ;2-4

2. Tornøe, C. W.; Christensen, C.; Meldal, M. J. Org. Chem. 2002, 67, 3057-3064. doi:10.1021/jo011148j

3. Themed issue: "Click chemistry: function follows form", guest Eds Finn M. G.; Fokin, V. Chem. Soc. Rev. 2010, 39, 1231-1405.

4. Meldal, M.; Tornøe, C. W. Chem. Rev. 2008, 108, 2952-3015. doi:10.1021/cr0783479

5. Díez-González, S. Catal. Sci. Technol. 2011, 1, 166-178. doi:10.1039/c0cy00064g

6. Lim, R. K. V.; Lin, Q. Chem. Commun. 2010, 46, 1589-1600. doi:10.1039/b925931g

7. Hong, V.; Presolski, S. I.; Ma, C.; Finn, M. G. Angew. Chem., Int. Ed. 2009, 48, 9879-9883. doi:10.1002/anie.200905087

8. Presolski, S. I.; Hong, V.; Cho, S.-H.; Finn, M. G. J. Am. Chem. Soc. 2010, 132, 14570-14576. doi:10.1021/ja105743g

9. Besanceney-Webler, C.; Jiang, H.; Zheng, T.; Feng, L.; Soriano del Amo, D.; Wang, W.; Klivansky, L. M.; Marlow, F. L.; Liu, Y.; Wu, P. Angew. Chem., Int. Ed. 2011, 50, 8051-8056. doi:10.1002/anie.201101817

10. Gaulier, C.; Hospital, A.; Legeret, B.; Delmas, A. F.; Aucagne, V.; Cisnetti, F.; Gautier, A. Chem. Commun. 2012, 48, 4005-4007. doi:10.1039/c2cc30515a 
11. Harmand, L.; Cadet, S.; Kauffmann, B.; Scarpantonio, L.; Batat, P.; Jonusauskas, G.; McClenaghan, N. D.; Lastécouères, D.; Vincent, J.-M. Angew. Chem., Int. Ed. 2012, 51, 7137-7141. doi:10.1002/anie.201203014

12. Harmand, L.; Lambert, R.; Scarpantonio, L.; McClenaghan, N. D.; Lastécouères, D.; Vincent, J.-M. Chem. - Eur. J. 2013, 19, 16231-16329. doi:10.1002/chem.201302032

13. Beniazza, R.; Lambert, R.; Harmand, L.; Molton, F.; Duboc, C.; Denisov, S.; Jonusauskas, G.; McClenaghan, N. D.; Lastécouères, D.; Vincent, J.-M. Chem. - Eur. J. 2014, 20, 13181-13187. doi:10.1002/chem.201404056

14. Beniazza, R.; Molton, F.; Duboc, C.; Tron, A.; McClenaghan, N. D.; Lastécouères, D.; Vincent, J.-M. Chem. Commun. 2015, 51, 9571-9574. doi:10.1039/C5CC01923K

15. Adzima, B. J.; Tao, Y.; Kloxin, C. J.; DeForest, C. A.; Anseth, K. S.; Bowman, C. N. Nat. Chem. 2011, 3, 256-259. doi:10.1038/nchem.980

16. Alzahrani, A. A.; Erbse, A. H.; Bowman, C. N. Polym. Chem. 2014, 5, 1874-1882. doi:10.1039/C3PY01064C

17. Gong, T.; Adzima, B. J.; Baker, N. H.; Bowman, C. N. Adv. Mater. 2013, 25, 2024-2028. doi:10.1002/adma.201203815

18. Gong, T.; Adzima, B. J.; Bowman, C. N. Chem. Commun. 2013, 49, 7950-7952. doi:10.1039/c3cc43637c

19. Tasdelen, M. A.; Yilmaz, G.; Iskin, B.; Yagci, Y. Macromolecules 2012 45, 56-61. doi:10.1021/ma202438w

20.Sandmann, B.; Happ, B.; Vitz, J.; Hager, M. D.; Burtscher, P.; Moszner, N.; Schubert, U. S. Polym. Chem. 2013, 14, 3938-3942. doi:10.1039/c3py00356f

21. Demirci, G.; Tasdelen, M. A. Eur. Polym. J. 2015, 66, 282-289. doi:10.1016/j.eurpolymj.2015.02.029

22. Tinmaz, H. B.; Arslan, I.; Tasdelen, M. A. J. Polym. Sci., Part A: Polym. Chem. 2015, 53, 1687-1695. doi:10.1002/pola.27612

23. Yagci, Y.; Tasdelen, M. A.; Jockusch, S. Polymer 2014, 55, 3468-3474. doi:10.1016/j.polymer.2014.06.068

24. McBride, M. K.; Gong, T.; Nair, D. P.; Bowman, C. N. Polymer 2014, 55, 5880-5884. doi:10.1016/j.polymer.2014.08.001

25. Tasdelen, M. A.; Yagci, Y. Tetrahedron Lett. 2010, 51, 6945-6947. doi:10.1016/j.tetlet.2010.10.166

26. Dadashi-Silab, S.; Kiskan, B.; Antonietti, M.; Yagci, Y. RSC Adv. 2014, 4, 52170-52173. doi:10.1039/C4RA09954K

27. Yetiskin, O.; Dadashi-Silab, S.; Khan, S. B.; Asiri, A. M.; Yagci, Y. Asian J. Org. Chem. 2015, 4, 442-444. doi:10.1002/ajoc.201500077

28. Motreff, A.; Correa da Costa, R.; Allouchi, H.; Duttine, M.; Mathonière, C.; Duboc, C.; Vincent, J.-M. Inorg. Chem. 2009, 48, 5623-5625. doi:10.1021/ic9005218

29. Abad, S.; Boscá, F.; Domingo, L. R.; Gil, S.; Pischel, U.; Miranda, M. A J. Am. Chem. Soc. 2007, 129, 7407-7420. doi:10.1021/ja0712827

30. Harmand, L.; Lescure, M.-H.; Candelon, N.; Duttine, M.; Lastécouères, D.; Vincent, J.-M. Tetrahedron Lett. 2012, 53, 1417-1420. doi:10.1016/j.tetlet.2012.01.035

31. Zhang, G.; Yi, H.; Zhang, G.; Deng, Y.; Bai, R.; Zhang, H.; Miller, J. T.; Kropf, A. J.; Bunel, E. E.; Lei, A. J. Am. Chem. Soc. 2014, 136, 924-926. doi:10.1021/ja410756b

\section{License and Terms}

This is an Open Access article under the terms of the Creative Commons Attribution License

(http://creativecommons.org/licenses/by/2.0), which permits unrestricted use, distribution, and reproduction in any medium, provided the original work is properly cited.

The license is subject to the Beilstein Journal of Organic Chemistry terms and conditions:

(http://www.beilstein-journals.org/bjoc)

The definitive version of this article is the electronic one which can be found at:

doi:10.3762/bjoc. 11.211 